
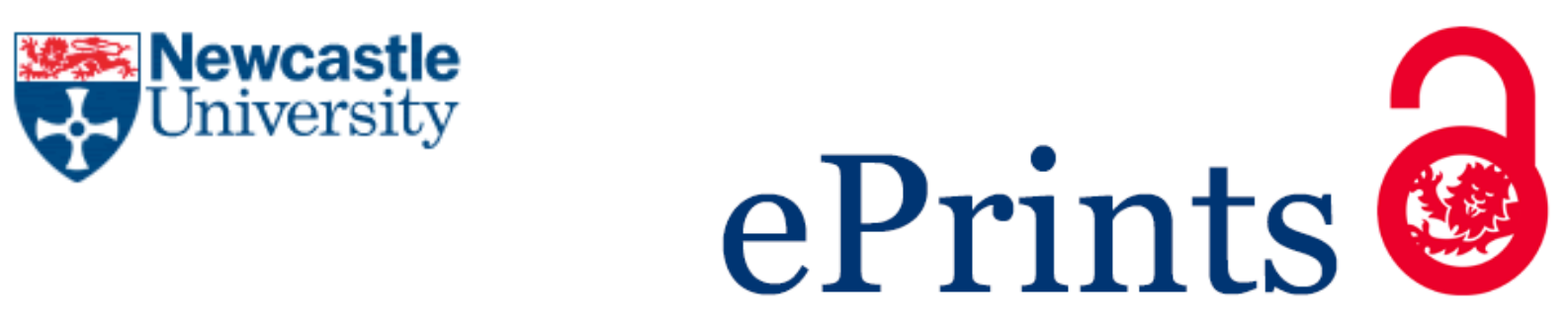

Yakovleva N, Vazquez-Brust DA.

Multinational mining enterprises and artisanal small-scale miners: From

confrontation to cooperation.

Journal of World Business 2017

DOI: https://doi.org/10.1016/j.jwb.2017.08.004

Copyright:

(C) 2017. This manuscript version is made available under the CC-BY-NC-ND 4.0 license

DOI link to article:

https://doi.org/10.1016/i.jwb.2017.08.004

Date deposited:

$08 / 11 / 2017$

Embargo release date:

16 April 2019

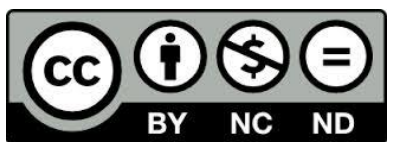

This work is licensed under a

Creative Commons Attribution-NonCommercial-NoDerivatives 4.0 International licence 


\title{
Multinational mining enterprises and artisanal small-scale miners: from confrontation
}

\section{to cooperation}

Natalia Yakovleva (1)* and Diego Alfonso Vazquez-Brust (2)

(1) Newcastle University London, Newcastle University, 102 Middlesex Street, London, E1 7EZ, email: natalia.yakovleva@ newcastle.ac.uk, tel: +44 2037522448

(2) Portsmouth Business School, University of Portsmouth, Portland St, Portsmouth, Hampshire, PO1 3DE, email: diego.vazquez-brust@ port.ac.uk, tel: +44 2392844600

* corresponding author

\begin{abstract}
In many developing countries, multinational enterprises (MNEs) in mining operate alongside fast-growing communities of informal artisanal, small-scale miners. This has led to direct conflict and competition for mineral resources. This paper introduces the Salience and Institutional Analysis and Design framework as a means to analyze the MNE strategies used to address informal miners across different governance levels in the gold mining sector of Ghana and discusses the implications of these strategies for sustainability. We identify the emergence of a cooperative strategy with informal miners as a sustainable alternative to the political strategy of reliance on the state to protect tenure.
\end{abstract}

Keywords: MNEs, CSR, artisanal mining, IAD, stakeholder salience, informal economy 


\section{Introduction}

The growth in foreign direct investment (FDI) in mining in emerging markets has been criticized for contributing to rising inequality and marginalization of communities that historically rely on artisanal, small-scale mining, posing a distinctive, sustainable development challenge (Aubynn, 2009). Artisanal, small-scale mining (ASM) that uses rudimentary techniques to mine gold, precious minerals, and coal is the most common form of mining in developing countries and is widespread in poverty-stricken communities (Verbrugge \& Besmanos, 2016). It is a labor-intensive activity that can be formalized, where artisanal miners receive legal approvals from the state, or informal, where miners work without formal licenses (Tschakert \& Singha, 2007). The ASM sector provides direct employment to an estimated 15 million people in 80 countries worldwide, supporting the livelihood of up to 100 million people (WB, 2009). At the same time, ASM poses serious challenges to sustainability due to poor health and safety measures, the use of child labor, and ineffective environmental protection due to the use of mercury (OECD, 2015; Veiga et al., 2014).

Since the 1990s, liberalization of investment regimes and mining codes in many developing countries has increased mining FDI in countries with a tradition of ASM. Simultaneously, informal ASM has rapidly expanded in the Global South, driven by rising commodity prices and lack of employment opportunities. This has led to direct competition

and rivalry for mineral resources between mining multinational enterprises (MNEs) and artisanal miners (Hirons, 2014). Mining MNEs experience a unique dilemma when faced with concessions, legally acquired from the state, that are occupied by communities of artisanal miners. When attempting to remove artisanal miners by force, it increases operational and reputational risks for mining MNEs (Veiga et al., 2014). This study focuses on the role of mining MNEs in the shift from confrontation to cooperation with artisanal 
miners and the consequences for sustainability. It argues that the role of the mining MNEs in the governance of mineral resources and relations with informal rivals has not been adequately conceptualized in international business and corporate sustainability literature.

Literature on MNEs, corporate social responsibility (CSR), and sustainability does not focus on the rivalry between MNEs and illegal users of resources, who are treated as fringe stakeholders without salience. When it comes to the control of assets and protection of property rights in host countries, international business research often focuses on MNE relations with host governments, using political risk theory and political strategy (Boddewyn, 2016; Stevens et al., 2016; Ramamurti, 2004; Zheng et al., 2016). A political strategy to defend property rights relies on strengthening the links with the state to improve the security of the tenure (e.g., using forced evictions and formalization policies), but fails to consider implications for sustainable development, especially poverty and inequality (Luo \& Zhao, 2013). Therefore, we need to look beyond the international business and CSR literature to find the appropriate conceptual means to explore sustainable and inclusive strategies for MNEs operating in complex institutional environments in emerging markets (Doh \& Teegen, 2002; Peng et al., 2008).

To address this gap, this study proposes a new framework to analyze the interactions between MNEs and informal resource use competitors: the Salience and Institutional Analysis and Design (SIAD) framework, built on the elements of stakeholder theory and Institutional Analysis and Design (IAD), and developed outside the international business literature. The IAD framework, originally from the field of economics (Ostrom, 1990, 2010; Paavola, 2007, 2016), examines conflict, rivalry, and competition over natural resource use, where actors draw on formal and informal rules. IAD studies the interactions between human activities in their biophysical and cultural contexts across three interlinked governance levels: operational (i.e., day to day interactions), collective-choice (i.e., organizational and field level 
rules), and constitutional (i.e., formal and informal institutions). As a framework, rather than a theory, IAD organizes academic research and can be complemented by other theories to fit a given research objective (Koontz, 2006). In order to contribute to the growing discussion about the role of mining MNEs in sustainable development, we integrate IAD (Ostrom, 2010; Paavola, 2016) with the stakeholder salience perspective that explains how companies act to satisfy stakeholder claims around natural resource use (Mitchell et al., 1997; Dahan et al., 2015; Erdiaw-Kwasie et al., 2017).

The emerging SIAD framework is applied to examine the stakeholder management strategy of mining MNEs focusing on cooperation with informal artisanal miners as an alternative to a political strategy relying on a state policy of exclusion of unauthorized users. The study analyzes how and why mining MNEs changed their approach to informal miners from confrontation to cooperation and how the assessment of the informal miners shifted from fringe to core stakeholders. Empirical evidence is based on the qualitative analysis of 26 semi-structured interviews conducted with a range of stakeholders in the Ghanaian gold mining sector in 2005 and 2008.

This paper makes several contributions to the literature on mining MNEs. First, we suggest that the strategic choice of cooperation with informal rivals for resources emerges at the operational level in recognition of the growing stakeholder salience of the informal miners. This occurs when political strategy is unable to deliver the effective exclusion of unauthorized users, which results in failures of the state and MNEs to expel or dissuade them. Second, we contend that a cooperative strategy implemented across governance levels can not only reduce MNE conflicts with informal users, thus assuring sustained access to resources, but can also contribute to poverty alleviation and reduced inequality. We find that MNE cooperation with informal miners increases the legitimacy and salience of these miners in the eyes of the government and other stakeholders, in a process of "legitimization through 
engagement." Cooperation can also achieve goals of environmental protection by reducing negative environmental impacts arising from the poor resource use practices of the informal miners (e.g., the use of mercury in artisanal mining and uncontrolled land disturbance). Third, we argue that a cooperative strategy works at the collective-choice level of governance when it bridges competing formal and informal institutions that affect the operations of the MNEs in the context of weak national institutions in emerging markets. Finally, we argue that MNE strategies need to be supported by a dynamic stakeholder salience assessment because stakeholders can gain and lose salience and move from fringe to core and vice versa across different governance levels over time.

The next sections review CSR and international business literature on strategies used by mining MNEs to deal with resource use rivals, then outline IAD and stakeholder salience frameworks. These sections are followed by discussions of the Ghanaian ASM context, research methods, findings, implications for theory and management practice, and the conclusion.

\section{Management of conflicts over natural resources}

\subsection{CSR and international business}

The occupation of mining concessions by informal artisanal miners in Ghana presents an urgent challenge for MNEs. International business research has examined the relationship between mining MNEs and local communities in host countries from the perspectives of CSR (Frynas, 2010; Kapelus, 2002; Zheng et al., 2015), sustainable development (Kolk, 2016; Kolk et al, 2017; Svensson et al., 2010), stakeholder theory (Crilly, 2011; Doh \& Teegen, 2002; Fassin, 2010; Friedman \& Miles, 2002), and bottom of the pyramid sourcing and market entry (Prahalad, 2006). The literature provides insights into the roles of local 
communities in developing countries as suppliers, customers, engaged recipients of MNEs' CSR projects, as well as challengers of unsustainable MNE practices, and providers of societal legitimacy and human capital resources to MNEs (Gifford et al., 2010).

However, these perspectives are not useful for dealing with fringe stakeholders that are seen by the state as illegitimate trespassers (Tschakert \& Singha, 2007). To date, the literature has paid limited attention to antagonistic relationships between MNEs and fringe stakeholders who lack legal legitimacy but compete with MNEs for access to natural resources. Antagonistic relations within MNEs and communities have been studied in social movements and anti-globalization literature (Bebbington, 2012; Kraemer et al., 2013). Social movement literature investigates collective efforts to change society, comprised of people united by a common set of beliefs about a preferred state of the world (Den Hond \& De Bakker, 2007). However, poor communities competing with MNEs for the use of mineral resources on their concessions do not disrupt business operations as a means of antiglobalization protest or part of social movements. Unregulated ASM is not a result of coordinated efforts to change society; rather, it is an ingrained activity of subsistence and livelihood. Rivalry with MNEs is the outcome of a lack of structural alternative means for subsistence. Thus, artisanal miners do not fit into any of the roles allocated to communities in the literature on CSR and sustainability in international business.

When faced with competing claims, a natural strategy for an MNE is to stay within the bounds of regulation and side with legitimate stakeholders such as the state. To reduce political risks, such as insecure tenure, MNEs often choose a political strategy by developing closer relations with the state to achieve beneficial outcomes from public policies (Khanna \& Palepu, 2010; Hillman \& Hitt, 1999; Luo \& Zhao, 2013; Zheng et al., 2016). With political strategies, MNEs rely on state intervention to protect property rights and solve conflicts with unauthorized parties (Boddewyn, 2016; Dunning, 1988, 1998; Holmes et al., 2013; Stevens et 
al., 2016; Ramamurti, 2004). If political strategies fail, the options are to exit or wait (Khanna \& Palepu, 2010). However, neither of these strategies presents a sustainable solution. Forceful eviction of artisanal miners increases inequality and their marginalization, while exit or wait strategies deprive the host country of investment and fail to address the negative environmental impacts of unregulated ASM on sustainability. We now explore the IAD as an alternative framework to find sustainable solutions to the resource rivalry between MNEs and artisanal miners.

\subsection{Institutional approach to natural resource governance}

The IAD framework (Ostrom et al., 1994; Ostrom, 1990, 2010) analyzes the outcomes of human activities focusing on interactions between institutions, individual decision-making, and aspects of the physical world and community culture. Ostrom proposed IAD as a foundation to explore the underlying complexity of interrelated social and ecological sustainability challenges "to build a solid field of sustainability science" (Ostrom, 2007, p. 182). IAD examines conflict and competition over natural resources and argues that selfregulation and community cooperation offer a sustainable governance solution to management of natural resources as an alternative to private property and external authority.

In emerging markets, where informal institutions often hinder implementation and enforcement of formal regulation (Peng et al., 2008), the literature on community management of common-pool resources can provide insights into collaboration between MNEs and informal resource rivals in response to failures of the state to protect $\mathrm{MNE}$ property rights in a manner compatible with sustainable development.

Common-pool resources, such as fisheries, aquifers, or grazing areas, have two defining characteristics: a) low excludability, where it is difficult to exclude unauthorized 
users; and b) high subtractability, where every time an actor uses the resource, less is left for others to use, leading to high levels of rivalry and conflict over consumption (Ostrom et al., 1994; Ostrom, 2010). A stable governance solution to competition over common-pool resources requires a community of actors, united by a common goal to preserve resources for continued use, to negotiate, monitor, and enforce the rules to protect and manage resources for the community benefit (Clement, 2010; Ostrom \& Gardner, 1993). Following SaldarriagaIsaza et al. (2013), we argue that gold deposits that can be extracted with artisanal means share the defining characteristics of common-pool resources.

IAD conceptualizes three interlinked governance levels where actors operate and action takes place; each functional level is regulated by corresponding institutional rules. The operational level is where rules or decisions about resource access are implemented and impact the physical world. The collective-choice level is where rules that govern resource use are designed and applied or where policy-making is conducted. The constitutional level is where rules of a higher order that affect both collective-choice and operational levels are made. These rules are difficult to change, as they define eligibility to design and participate in policymaking (Ostrom, 1990; Ostrom et al., 1994).

Paavola (2007, 2008) proposed three types of governance solutions to resolve resource conflict: state-based, community-based, and co-management. The latter conciliates private ownership with collective ownership to ensure successful outcomes for interested parties. A well-designed governance solution should provide institutional rules of exclusion, entitlement, monitoring, and decision-making in order to support seven major governance functions of resource management: 1) exclusion of unauthorized users; 2) regulation of authorized resource use and distribution of benefits; 3) provisioning of goods and recovery of costs; 4) monitoring of resource users; 5) enforcement of resource use rules; 6) resolution of conflicts, and; 7) collective-choice for modification of solutions. If these functions are not 
effectively fulfilled at all three governance levels, the governance system will be unstable and eventually collapse (Paavola, 2016).

An effective solution should provide low monitoring and enforcement implementation costs, and promote social justice and environmental protection (Dietz et al., 2003). Community-based and co-management solutions have lower implementation costs because users often monitor each other and enforce rules (Paavola, 2016). Mutual trust and acceptance of rules as legitimate among community members are essential for communitybased monitoring and enforcement (Dietz et al., 2003; Ostrom, 2010). IAD has relevance for international business in situations when MNEs attempt to secure tenure (i.e., the exclusion of unauthorized users) using political strategies or reliance on state-based governance solutions. MNEs can only succeed if a state-based solution can resolve the causes of conflicts between MNEs and ASM over resource use, monitor resource users, guarantee fair distribution of benefits, and gather collective-choice support for the exclusion of informal artisanal miners.

The IAD framework can benefit international business research by examining the negotiation of rules between companies and other stakeholders across various governance levels (Ostrom, 1990, 2010), exploring their effects on the institutional environment in which MNEs operate and the outcomes for sustainable development such as poverty, inequality, wellbeing, and environmental protection (Batjargal et al., 2013; Holmes et al., 2013).

The IAD perspective, where formal and informal rules are equally legitimate as far as they contribute to the sustainable use of resources, provides the foundation from which to discuss cooperation over common goals and resources between MNEs and other actors, whether or not they are legally entitled to use the resources in conflict.

International business research on property rights offers MNEs two strategies if the state fails to protect property rights: exit or wait (Khanna \& Palepu, 2010). The IAD 
framework offers a third: MNEs can step in to regulate the conflict themselves through cooperation with informal rivals.

The IAD framework has been criticized for an absence of power in its analysis (Clement, 2010). The framework does not enable a firm-level analysis, nor does it explain how for-profit businesses engage in decision-making that affects organizational goals, for instance, why an MNE may choose a cooperative strategy rather than a political one. We now explore stakeholder theory to address these limitations and to complement IAD in order to explain the strategic choices among the MNE strategies dealing with informal miners.

\subsection{MNEs and stakeholder management}

Stakeholder theory is a useful framework to analyze the relationships between MNEs and local actors in host countries and has been widely used to develop CSR programs (Donaldson \& Preston, 1995; Fassin, 2010). A stakeholder is "any group or individual who can affect or are affected by the achievement of the firm's objectives" (Freeman, 1984, p. 46). MNEs are encouraged to develop constructive dialog with stakeholders on issues of mutual concern to achieve mutual benefit (Ali, 2017). When MNEs benefit local stakeholders, they can achieve organizational goals (Donaldson \& Preston, 1995; Phillips et al., 2003) and contribute to sustainability in emerging markets (Gifford et al., 2010; Campbell et al., 2012). For instance, mining MNEs can build legitimacy and reduce their liability of foreignness when they implement CSR programs (Kostova \& Zaheer, 1999; Frynas, 2010; Gifford et al., 2010; Zheng et al., 2015). Mining MNEs often negotiate legal and voluntary procedures for land access, acquisition, relocation, and compensation with stakeholders such as local communities and indigenous peoples (Keenan et al., 2016) who have legal rights to access natural resources (e.g., land, forests, water, and biodiversity resources) in and around 
mineral concessions and can be negatively affected by mining operations (Bebbington, 2012; Kraemer et al., 2013).

Understanding how managers assign priorities to various stakeholders and their claims can help identify suitable stakeholder management strategies for MNEs (Bundy et al., 2013). Mitchell et al. (1997) prioritize "core" or salient stakeholders that exhibit all three attributes of legitimacy, power, and urgency of claims. Conversely, "fringe" stakeholders lack one or more of these attributes, and thus, have limited salience (Hart \& Sharma, 2004). Fringe stakeholders can be adversarial, poor, disinterested, divergent, isolated, weak, or illiterate parties.

Power is the ability of one social actor to influence another social actor to do something that the latter would not have done otherwise (Mitchell et al., 1997). Power can be coercive, utilitarian, or normative and can be obtained by formal, political, economic, and relational means (e.g., centrality in stakeholder networks, alliances, and coalitions) (ErdiawKwasie et al., 2017).

Legitimacy is "a generalized perception or assumption that the actions of an entity are desirable, proper, or appropriate within some socially constructed system of norms, values, beliefs and definitions" (Suchman, 1995, p. 574). Legitimacy can be pragmatic, which relates to self-interest, benefit, exchange, and influence; moral, which relates to a positive normative evaluation of an actor and his/her activities; and, cognitive, which relates to taken-for-granted cultural perspectives (Suchman, 1995). The assessment of stakeholder legitimacy and claims legitimacy is a social process that is co-determined by managers and other stakeholders, especially the government (Tashman \& Raelin, 2013). Actors without legal legitimacy or groups engaging in illegal activities should be treated as non-stakeholders (Fassin, 2010). 
Illegitimate groups or organizations do merit consideration but attention to their claims is not focused on developing mutually beneficial relationships (Ali, 2017).

Urgency is the degree to which stakeholder claims call for immediate attention (Mitchell et al., 1997). Urgency comprises time sensitivity (i.e., how important a claim is for the stakeholder) and criticality (i.e., to what extent delays on attending to the claim are unacceptable to the stakeholder and how actively the stakeholder is pursuing the claim). Urgency is increased by frequency of interaction between a firm and the stakeholder (Driscoll \& Starik, 2004). Agle et al. (1999) found that urgency was the strongest predictor of salience.

Salience perceptions are dynamic; managers prioritize and de-prioritize a stakeholder's status over time (Khurram \& Charreire Petit, 2017). Stakeholders gain salience through acquiring resources that increase their size, developing unique capabilities and advantages through coalition building or responding rapidly to the organization's actions (Doh \& Teegen, 2002). Illegal entities can acquire legitimacy over time, such as the emancipatory movements fighting colonial powers that were once considered terrorists or criminals (Ali, 2017).

Stakeholder assessment is not independent from other stakeholder views (Dahan et al., 2015). The salience of a stakeholder can change when another salient stakeholder, such as a non-governmental organization, state institution, or another business, empowers these stakeholders by enhancing their capacity to make choices and transform those choices into desired actions and outcomes (Erdiaw-Kwasie et al., 2017). The business-governmentcommunity nexus framework suggests these parties can support or undermine each other's salience (Dahan et al., 2015). The government is a key stakeholder that amplifies the salience of other stakeholders; MNEs often rely on the government to frame the relations with other stakeholders in host countries (Dahan et al., 2015). 
A major criticism of stakeholder theory is its firm-centric view of actors (Ali, 2017; Friedman \& Miles, 2002). Integrating stakeholder salience with IAD addresses such criticism. The new SIAD framework expands the business-government-community nexus to analyze relations between the stability of governance solutions and changes in stakeholder salience at operational, collective-choice, and constitutional levels of governance.

We now examine the context of ASM and mining MNE operations in Ghana.

\section{Conflict between informal artisanal miners and mining MNEs in Ghana}

Artisanal gold mining in Ghana dates back hundreds of years, preceding mechanized large-scale mining in the country (Hilson et al., 2007). Historically, artisanal mining was a community-led activity, which adhered to the rules enforced by customary authorities (i.e., chiefs who govern land and community relations in Ghana) who sanctioned mining and partook in its earnings. Under colonial rule, gold mining funded by foreign capital was conducted closer to the coast, leaving artisanal mining undisturbed in the rest of the country. After independence, the state attempted to limit customary authority by centralizing the governance of mineral resources under the central government, nationalizing, and later privatizing, large-scale mining (Hirons, 2014). Since the 1980s, new legislation has encouraged inward FDI. The Minerals and Mining Law of 1986 introduced tax reductions, variable royalties, unrestricted dividend transfers, and reduced import duties. The state granted prospecting and exploitation rights to mining MNEs, distributed concessions around the country, and succeeded in attracting inward FDI, which became an important source of industrial growth and foreign currency earnings (Tschakert \& Singha, 2007). Negotiations on new mines between the central government and mining MNEs excluded the interests of artisanal miners and customary authorities (Hilson et al., 2007). 
Artisanal miners could not acquire prospecting and exploitation licenses until the introduction of the Small Scale Mining Law of 1989 (Hirons, 2014). Due to the three-year regulatory gap, artisanal miners (locally called galamsey - a corruption of the expression "get them and sell"), who operated on lands granted to mining MNEs, gained the status of illegal or informal miners. Operational shortcomings of the Small-Scale Mining Law of 1989 discouraged many poor artisanal miners from formalizing and applying for licenses. Instead, artisanal miners continued operating with the approval from local chiefs using informal, customary rules (Hilson et al., 2007; Tschakert \& Singha, 2007).

Growth of informal ASM in Ghana has exposed the inadequacy of the country's regulatory system, highlighting the inability of the state to secure the exclusivity of the mineral rights to mining MNEs on awarded concessions. The spread of informal mining on MNEs concessions has led to conflicts, causing operational risks for mining MNEs and societal concerns for health and safety, environmental pollution, use of mercury, gender discrimination, and child labor (Bush, 2009; Hirons, 2014; Tschakert \& Singha, 2007; Veiga et al., 2014).

From 1989 to 2008, the government delivered a series of initiatives to formalize ASM with the assistance of the United Nations, the World Bank, and other international organizations (Yakovleva \& Vazquez-Brust, 2014). These initiatives were aimed at controlling mercury pollution, enhancing the state capacity to enforce regulation, relocating and confining ASM to specific land sites, and providing alternative employment opportunities to displaced miners (e.g., the Prestea Action Plan funded by the World Bank in 2005). These top-down, state-based solutions to the governance of mineral resources failed to formalize the entire ASM sector, leaving mining MNEs vulnerable to trespass from local artisanal miners. By 2008, when these initiatives were completed, $80 \%$ of small-scale miners in Ghana were still unregistered, employing as much as 300,000 people (Hirons, 2014). 
When CSR initiatives to divert local communities from mining failed, some mining MNEs started to accept informal miners on their concessions, although this conflicted with the concession conditions (Aubynn, 2009).

\section{Research methods}

This research followed a case study approach (Yin, 2003) involving the longitudinal analysis (2005-2008) of activities of three gold mining MNEs operating in Ghana, two of them headquartered in the United States and one headquartered in South Africa. Two of the MNEs commenced operations in the 1990s and one in the 2000s. All experienced massive trespassing by informal miners.

We analyzed secondary data on state-led initiatives (1994-2008) and corporate annual reports (2005-2008). This complemented primary data from 26 semi-structured interviews with managers from the mining MNEs and various stakeholders in Ghana conducted in 2005 and 2008 (see Table 1). Interviewees were selected using the snowballing technique (Gifford et al., 2010; Kapelus, 2002); the initial interviewees were identified from core public and private actors in the Ghanaian gold mining sector. These were formally approached with letters and consent was sought for conducting interviews. Access to interviews with smallscale miners was obtained through a traditional paramount chief who supported the project. Interviewing different actors allowed us to verify the findings and check for convergence between sources through triangulation (Yin, 2003). Seven key actors were interviewed both in 2005 and 2008. In 2008, we did not directly interview small-scale miners but analyzed the changes in their situation using secondary data. Interviews were recorded and later transcribed verbatim. Field notes were taken during the fieldwork and provided contextual support for the analysis. 


\section{INSERT TABLE 1}

Analyses were conducted using a staged coding approach (Charmaz, 2006; Lincoln \& Guba, 1985). Emergent (inductive) and a priori codes (deductive) were developed to interpret the data (Charmaz, 2006). Thick description narratives, which are defined as accounts of organizational behavior in a context aimed at extracting meaning (Lincoln \& Guba, 1985), were developed for individual interview transcripts and later aggregated by stakeholder type. In the process of thick description narration, emergent inductive coding themes were identified. Emergent themes signify patterns of data that describe the phenomenon and relate data to a research question (Charmaz, 2006). A priori, deductive codes were created to analyze the data and relate the study to the theoretical framework (Charmaz, 2006). Two researchers separately coded all the data using emergent and a priori codes. Both manual and computer assisted qualitative analysis (NVivo 10 software) were used. Researchers exchanged coding results and narrative descriptions for further interpretive analysis and writing.

Emergent codes were developed for MNE led initiatives, government led initiatives and rules, customary authorities and informal rules, cooperative interactions, antagonistic interactions, unemployment, tradition, social sustainability, environmental sustainability, economic development, profits, success, failures, and shifts in perception. A priori codes drawn from IAD included: a) governance levels - operational, collective-choice and constitutional, and b) institutional rules of exclusion, entitlement, monitoring, and decisionmaking (Paavola, 2008). Additionally, interviews were searched and coded for stakeholder salience attributes: 1) power - coercive, utilitarian, and normative (Mitchell et al., 1997); 2) 
legitimacy - pragmatic, moral, and cognitive (Suchman, 1995), and legal (Agle et al., 1999); 3) urgency - time-sensitivity and criticality (Mitchell et al., 1997) and, 4) proximity geographical and emotional (Driscoll \& Starik, 2004).

\section{Results: Applying Salience and Institutional Analysis and Design}

\subsection{Political and cooperative strategies for informal mining}

The institutional environment where mining MNEs operate and interact with ASM in Ghana consists of two distinct regimes for managing natural resources: state-led and customary. The formal state regime centers on state authority. The government sanctions the rules of exclusion of unauthorized users, entitlement, and monitoring. Decision-making is focused on interests of the state and the state-authorized mining parties: MNEs, registered ASM operators, and international organizations (i.e., funders of intervention programs). The state regime rests on the rule of law and principles of private property, securing minerals rights with registered users. The informal, customary regime centers on the authority of traditional chiefs, who sanction the rules of exclusion, entitlement, and monitoring. Decisionmaking focuses on interests of local communities including artisanal miners. The customary regime consists of historically developed informal rules embedded in traditional and cultural norms and applies to both registered, unregistered artisanal miners, and local communities. This makes it difficult for MNEs to distinguish between the informality of artisanal miners and the legitimacy of local communities.

In the 1990s and 2000s, mining MNEs followed a political strategy to secure tenure by building close links with the government to respect property rights. It included removal of informal miners by police and military forces and support of state-interventions to relocate informal miners to alternative sites. The political strategy involved MNEs relying on 
government policy to promote formalization in the ASM sector and public dialogue to convince informal miners to abandon occupied concessions. In addition, mining MNEs partnered with government and international organizations to deliver CSR initiatives, such as the Alternative Livelihood Program, geared towards poverty alleviation and aimed at diverting local communities from entering informal mining. The initiatives offered training and skill provision to local communities and encouraged alternative employment and livelihood opportunities; however, by 2005 , these had drastically failed to reduce informal mining.

Political strategy underestimated the resilience of the informal ASM sector and the strength of informal rules governing the sector, which are deeply embedded in rural communities: “...local people are benefiting [by ASM], they see the registered companies [MNEs] as a threat to their livelihood..." (manager, MNE A, 2008). Traditional chiefs exert considerable presence at the operational level by allowing access to mineral resources, while local communities support informal activities as morally and culturally legitimate. The political strategy of mining MNEs heavily overestimated the state capacity to regulate mineral resource use and deliver on functions of exclusion of unauthorized users, monitoring, and enforcement of rules. Public policy ignored the realities of artisanal mining communities, where poor communities were driven to artisanal mining seeking productive employment and income earning, and instead, insisted that informal miners should be excluded from accessing mineral resources and from the design of policy interventions.

The move from confrontation to cooperation started at an operational level. Following failures to enforce the exclusion of unauthorized users through public policy intervention, mining MNEs started to adopt a co-management governance solution with the ASM sector. MNEs cooperated directly with informal miners and co-existed on the same concessions, allowing them to mine in selected areas. MNEs also coached artisanal miners on adopting 
safer and sustainable mining practices. Thus, the artisanal miners were entitled by MNEs as resource-users and decision-makers at the operational level. "Yes, you are looking at a situation where they coexist because if you go to [the MNE Y]. There are some areas of low grade. And [the MNE] leaves some areas for the small-scale miners...as a means of helping them to get the plot and also minimize the trespassing and so on" (Government Official 8, 2008). This cooperation regulated conflict and included the artisanal miners and the MNEs jointly enforcing new rules of exclusion, with artisanal miners preventing new entrants from accessing the concession: “...small-scale miners... will fend-off new entrants...so there's a collaboration between the large-scale miners and small-scale miners...there is a need for the large-scale miners and the small-scale to coexist peacefully” (Government Official 7, 2008).

In 2005, cooperative strategies were kept at the operational level and adopted only by a few pioneering MNEs. By 2008, dissemination of successful outcomes resulted in a wider adoption of cooperative strategies at a collective-choice or field level. MNEs started to acknowledge the need to collaborate with informal miners in and around the concessions in their annual reports, while, at a global level, international mining associations started to discuss the possibilities of cooperation with informal miners as part of CSR and sustainable development strategies to aid poverty alleviation and reduce environmental pollution (see ICMM, 2009). Cooperative strategies were collectively endorsed by the mining industry because they enabled MNEs to formulate common rules across the sector. Mining MNEs sought cooperative arrangements with informal miners as opposed to direct confrontation. However, the success of such cooperative strategies rested on mutual trust. "They must trust you... When you say you will do this, you do it...You must be seen to be doing something for the community and you must let them know that you can develop some alternative programs" (manager, MNE A, 2008). 
As the political strategy relies on the state enforcing exclusion and entitlement rules, failure means that MNEs cannot achieve their aim of property right protection. The cooperation with informal miners constitutes a new MNE strategy in securing tenure and contributing to sustainable development. It relies on collective action involving MNEs, artisanal miners, and customary authorities. It shifts the functions of exclusion of unauthorized users, regulation of authorized use, enforcement, and monitoring of rules into the sphere of negotiation between mining MNEs and selected informal miners (see Table 2).

\section{INSERT TABLE 2}

The benefits of the MNE cooperative strategies include the reduction of conflict, improved security of mineral operations, and control of land, mineral resources, and environmental degradation. It is a suitable response to the institutional environment, characterized by the presence of formal and informal rules at various levels. However, the stability of this co-management governance solution relies on the maintenance of negotiated informal rules. Since there are limitations for both political and cooperative strategies to deliver stable solutions benefiting the business objectives of mining MNEs, we assume that MNEs use both political and cooperative strategies in this challenging institutional environment.

\subsection{Shift in the stakeholder salience assessment by mining MNEs and the government}

In 2005, unregistered artisanal miners were considered illegitimate, criminal trespassers who should be removed from mineral concessions by force. By 2008, informal 
miners were acknowledged to be part of local communities whose claims were addressed by business strategies at operational and collective-choice levels. This shift in attitudes was a result of the increased salience of the informal miners, changing their status from fringe to core stakeholder, and this is demonstrated through the attributes of urgency, power, and legitimacy.

Urgency: MNEs' perception of the urgency of the claims of artisanal miners grew from several elements: a) artisanal miners' abilities to physically occupy land and cause disturbances to business operations; b) negative impacts of unregulated ASM on sustainability, causing environmental pollution, augmenting health, safety, and environmental risks, and increasing compliance costs; c) escalation of artisanal miner numbers at the concession and their capacity to resist forceful removal; d) prolonged impact on MNE activities owing to change from sporadic to permanent ASM camps; e) ASM gaining local community support through offering jobs, income, and support for local economies. Proximity also contributed to urgency (Driscoll \& Starik, 2004). Not only the geographical proximity of artisanal mining occupying concessions, but also the economic and cultural closeness of artisanal miners with local communities, which considered them as legitimate community members.

Initially, MNEs considered local communities residing around the mines as salient stakeholders, but refused to acknowledge artisanal miners as legitimate community members. Such assessment was influenced by government officials who dismissed artisanal miners as opportunistic nomads. Later, MNEs and the government had to recognize the undeniable link between artisanal mining and the livelihood of rural communities. "They are the community. You have to work with the community" (Government Official 5, Ghana, 2008). By 2008, the boundary between artisanal miners and local communities had blurred. Local community members, including women, youths, local farmers, and other rural workers, had joined the 
ranks of artisanal miners on a temporary, seasonal, or permanent basis. The urgency of addressing the specific issue of artisanal mining had spilled over into the area of local community and social relations for the MNEs. The support that local communities and traditional authorities extended to artisanal miners indicates that ASM salience grew not only at the operational level but at the collective-choice level, where salient stakeholders treated artisanal mining as an urgent community issue.

Power: By 2008, informal artisanal miners had gained coercive, utilitarian, and normative power at the operational and collective-choice levels. Their coercive power relates to their ability to resist expulsion, their persistence in returning to the concessions, and the ease in which local laborers can enter informal sectors, reducing the effectiveness of formal exclusion and monitoring rules implemented by the state and companies. Growing organizational, technical, financial, and labor resources at the disposal of unregistered artisanal enterprises increased their utilitarian power with communities and their power to effect change at operational and collective-choice levels. The normative power of artisanal miners is linked to the customary regime, which uses informal rules of entitlement to access and extract resources and customary authorities. Although the customary regime was in decline due to state policies and community undermining of traditional norms, artisanal mining represented a community-based management of resources, a way to continue cultural traditions and rules.

Geographical spread and countrywide pervasiveness of ASM commanded further collective action on the part of industry members and the government. Artisanal miners and supporting local communities could influence political processes through voting and coalition building with other fringe stakeholders displaced by MNEs. ASM visibility rose during political elections and quickly became a matter of public debate nationally and internationally, attracting the attention of academia and civil society organizations. 
Legitimacy: Although lacking legal legitimacy, informal miners gained moral legitimacy among various organizational stakeholders such as local communities and civil society organizations. The issue of poverty alleviation and rural unemployment had changed the perceptions of artisanal miners from "criminal trespassers" to "local communities earning their livelihood." The initial assessment of informal miners as illegal and even criminal had informed public policy and formalization interventions, excluding informal miners from consultation and the design of interventions. Lack of cooperation with informal miner claims reduced the effectiveness of public policy intervention on which the political strategy of the MNEs relied.

Poverty alleviation and the promotion of rural livelihoods had become part of the public policy agenda that legitimized the moral claims of informal miners. Applying forceful expulsion of poor communities from accessing mineral resources to support livelihoods raised questions of the violations of human rights, exposing both government policy and companies' actions to criticism from civil society organizations. A change in managers' and government officials' perceptions took place both at operational and collective-choice levels. At the collective level, the Ghanaian Chamber of Mines started to acknowledge the plight of unregistered miners, companies started to acknowledge the legitimacy of informal miners in their corporate reports, and the international mining association discussed cooperation with artisanal miners (ICMM, 2009). Once the legitimacy of the informal miners had grown at the collective-choice level, the government's assessment of the legitimacy of the artisanal miners did a U-turn (see Table 3). In 2008, government officials endorsed the cultural legitimacy of artisanal mining rooted in the history and traditions of rural communities in Ghana. "I know small-scale mining in Ghana had been like part and parcel of the people because small scale gold mining in this country dates as far back as 15th century. They have been the system for 
all these years, we cannot pretend they are not part of the system now" (Government Official 3, 2008).

INSERT TABLE 3

We can see the pattern of the increased stakeholder salience of the artisanal miners across different governance levels, resulting in the social upgrading of these informal economy actors. The bottom-up amplification of the artisanal miner salience among MNEs started at the operational level through the artisanal miners' coercive power, then moved upwards to the collective-choice level, gaining legitimacy in the eyes of other legitimate stakeholders such as customary authorities and local communities. MNEs started to formalize cooperative agreements with selected informal mining groups. Following the success of MNEs' cooperative strategies, the government reassessed the salience of artisanal miners and created public policy to address the entire ASM sector, both registered and unregistered. At the constitutional level, however, the state regime maintained formal rules of exclusion of unregistered actors from accessing mineral resources.

\section{Discussion}

The linkages among the informal economy, inequality, and poverty have long been established by development economists (Ostrom, 2007), who emphasized the responsibility of formal actors to engage in the social upgrading of informal economy actors (Rivera-Santos et al., 2015). While the focus of economists has been on state policy, the role of MNEs in this social upgrading process is still unclear. Despite the emerging CSR literature investigating the relationships between business and informal economy actors in Africa (Rivera-Santos et al., 2015; Demuijnck \& Ngnodjom, 2013; Lund-Thompsen et al., 2016), the antagonistic 
relations between MNEs and fringe stakeholders competing for the use of resources remains unexplored. There is lack of empirical evidence and theory to help understand the forces that can drive the cooperation and participation of the MNEs in social upgrading of informal rivals.

Our SIAD framework can contribute to address this outstanding gap, thus, enabling CSR policies of MNEs to align with stakeholder management strategy and more effectively target poverty alleviation and reduction of inequality. The SIAD framework helps to conceptualize the stakeholder management and cooperative strategy of the MNEs as a comanagement solution to natural resource governance, which is an alternative to political strategy that supports a state-based solution to natural resource governance (Dietz et al., 2003; Paavola, 2008). MNEs can assist in maintaining the successful governance of natural resources by cooperating with other resource users when state-based solutions are failing to deliver functions of exclusion, entitlements, and monitoring. Cooperation could become a stable governance solution when actors accept it as a legitimate solution to avoid further conflict (Ostrom, 2010; Paavola, 2016). The political strategy of MNEs to support state-based solutions to remove unauthorized ASM operators from accessing the resource has not only proven to be unsuccessful and confrontational but also damaging to the reputation of MNEs.

The political strategies of the MNEs were challenging due to several reasons. First, coexistence of competing formal and informal governance regimes complicate the institutional environment in which MNEs operate. Reliance on formal regulation faced operational level challenges. The government was not able to fully enforce formal monitoring and enforcement rules of resource management since informal rules were persistent at operational and collective-choice levels. Second, MNEs and government officials underestimated the power of informal users and customary authorities to influence corporate operations and their stakeholders. The growing power of informal miners derailed top-down 
formalization and relocation solutions. Third, the context of poverty and the significance of informal mining for rural economic development increased the legitimacy of ASM in the eyes of the public and local communities, reinforcing the claim that informal miners were fighting poverty and unemployment. The lack of alignment between MNEs' political strategies and context-sensitive stakeholder salience assessment leads to strategy failure and unwelcome outcomes such as conflict.

The SIAD framework contributes to incipient research on the role of MNEs in the implementation of the UN Sustainable Development Goals (SDGs) (e.g., Kolk et al., 2017). SIAD offers MNEs operating in developing countries, and wanting to contribute to SDGs, a new approach for dealing with poor and informal resource users through cooperation and network stakeholder appraisal. This will lead to social upgrading of informal economy actors, which is critical in achieving SDG1 (poverty alleviation), SDG8 (sustainable work and economic growth), SDG10 (reduced inequalities), and SDG16 (peace, justice, and strong institutions) (ILO, 2017).

The re-evaluation of poor and marginalized groups using a networked stakeholder appraisal will result in designing new and more inclusive corporate strategies for poor and marginalized groups when legitimate stakeholders, such as local communities, can help build the legitimacy of previously non-salient stakeholders. A greater involvement of MNEs with the SDGs and the uptake of corporate strategies for eliminating poverty and inequality can contribute to increasing the social legitimacy of MNEs in developing countries. The cooperative strategies of the MNEs successfully perform all governance functions at operational and collective-choice levels and contribute to the achievement of SDGs on poverty alleviation, reduction of inequality, and environmental protection (Dietz et al., 2003; Paavola, 2008). The use of the SIAD framework enables three important contributions to the field of research on MNEs and SDGs. First, as SDGs set national level objectives, the SIAD 
framework helps MNEs evaluate whether corporate strategies provide successful solutions to wider resource governance benefiting the nation (see Table 2). Second, the SIAD framework can help MNEs appraise stakeholder salience across different levels, operational, collectivechoice, and constitutional, thus, exposing MNEs to networked societal demands and allowing MNEs to navigate through a complex web of actors who have varying attributes of power, legitimacy, and urgency at different functional levels. Third, cooperation with informal users is a suitable corporate response to doing business in a polycentric institutional environment in developing countries (Batjargal et al., 2013), where informal and formal rules are at play and several centers of authority govern the institutional environment (Ostrom, 2010). Cooperation with informal rivals is not only essential to address developmental challenges, but also to the survival of foreign investment in countries where informal rules regulating economic activities are prevalent.

Our analysis demonstrates that the emergence of a cooperative strategy relates to the MNEs' reappraisal of stakeholder salience. Informal miners gained an important status as salient stakeholders, effectively moving from fringe to core in relation to the MNE strategies. This finding confirms that stakeholder salience is a dynamic process negotiated in the government-business-society nexus, where government, business, and community exchange knowledge on the urgency, power, and legitimacy of stakeholder claims (Dahan et al., 2015; Khurram \& Charreire Petit, 2017; Shivarajan et al., 2015). Further, local communities act as important catalysts in changing managers' perceptions about the legitimacy of social groups and their claims, especially by awarding them moral legitimacy.

Following government-business-community nexus theory (Dahan et al., 2015), we suggest that MNEs can increase the salience of marginal social groups by directly engaging with them and involving them in corporate strategies. We call this process "legitimization through engagement." MNEs legitimized fringe stakeholders by entering into cooperative 
strategies at the operational and collective-choice levels. As a result, the government started to accept the legitimacy of informal miners. Global stakeholders usually influence MNE decision-making, but in this case, they initially sided with the government in denying salience to informal miners and supporting state-based governance of mineral resources. Over the years, when cooperative strategies of MNEs proved successful, international organizations and global mining associations also changed their stance on artisanal mining and now promote greater cooperation (WB, 2009). However, informal miners do not yet warrant the status of core stakeholders at the constitutional level in the formal property regime, and a voluntary code of conduct for MNEs explicitly reinforces such an approach at the constitutional level.

We theorize that salience of a stakeholder group can differ depending on the level of governance; it can be considered salient at the operational and collective-choice levels, but not salient at the constitutional level. However, the salience of stakeholders across all governance levels is related, as knowledge about the stakeholder salience appraisal is shared in the government-business-community nexus. We suggest that core stakeholders can gain or lose salience and move across the institutional levels as depicted in Figure 1. When institutional rules change to exclude a stakeholder, the salience of these stakeholders is diminished and they can potentially be moved from core to fringe, as was the case with customary authorities who were deprived of salience by the formal property regime. We conclude that when a stakeholder moves from fringe to core at any governance level, existing MNE strategies become unstable. MNEs should start paying distinctive attention to claims of new core stakeholders, adapt to include them, and devise new corporate strategies accordingly. 


\section{INSERT FIGURE 1}

Contributing to the IAD literature, our study suggests that governance solutions to the management of resources, along with changes in stakeholder salience, can be initiated at constitutional, collective-choice, and operational levels of governance. Increased salience enhances formerly illegitimate stakeholders' capacity to make choices and transform those choices into desired actions and outcomes (Erdiaw-Kwasie et al., 2017). At the constitutional level, core stakeholders are those whose opinions count in setting the rules. At the collectivechoice level, core stakeholders are those whose interests are considered when rules are implemented. At the operational level, core stakeholders are those who influence operational level decisions. Thus, stakeholder salience and types of governance solutions (state-led, community-based, and co-management) can differ depending on the level of governance. We also suggest that both stakeholder salience and governance solutions will converge and stabilize over time when actors transfer knowledge used in making salience assessments and work together on a successful governance solution. Bottom-up cooperation arrangements that emerge at the operational level have the ability to move up to the constitutional level. For instance, amid government skepticism, MNEs started to cooperate with ASM in concessions at the operational level. This was later accepted by mining industry associations at the collective-choice level, and finally, the government supported these negotiated agreements as a key avenue to solve conflict in the mining sector.

These conceptual insights contribute to international business literature, the IAD framework, and stakeholder theory. In summary, SIAD suggests that: a) MNEs need to consider the implications for sustainable governance of resources when choosing corporate strategies to deal with informal resource users; b) salience is a function of the interactions in a 
web of stakeholders and must be studied when analyzing governance solutions; c) salience differs per level of governance considered; d) the salience of stakeholders included and excluded in a governance system and the stability of governance solutions are interdependent, and; e) differences in stakeholder perceptions of other stakeholders' salience can lead to flaws in the design of governance solutions, but such differences tend to stabilize over time. Our results are aligned with conceptual developments in stakeholder theory proposing that stakeholder salience is a social process, wherein salience is co-determined by stakeholders in stakeholder networks (Tashman \& Raelin, 2013).

Our study supports the relevance of the SIAD framework to international business research by examining institutional rules and functions of the resource use governance system in which MNEs operate. The SIAD improves the understanding of challenges faced by MNEs competing for resources with informal rivals. On its own, stakeholder salience is a narrow slice of corporate strategy. It does not touch on how corporate strategy can be guided by wider structures such as governance of resources that involve both state and non-state actors at different governance levels. Our integrative SIAD approach suggests that companies should not only rely on stakeholder analysis in decision-making affecting organizational goals and instead consider implications to governance solutions and sustainable development such as poverty alleviation and environmental protection. This mirrors the argument of Paavola $(2008,2016)$ that a successful governance solution should address sustainable development challenges.

By introducing stakeholder salience assessment, SIAD adds a power dimension to the IAD analysis. Firms accept cooperation in sharing resources with informal actors as an adaptive response to the mounting power and legitimacy of stakeholders. In our case, informal actors gained power through non-coordinated strategies of mobilization, formation of political networks, and interdependencies with communities as well as resilience and 
velocity in response to actions attempting their exclusion. This supports the proposition of Doh \& Teegen (2002): stakeholders strengthen their salience by acquiring resources, coalition building, and developing unique capabilities and rapid responses to organizational actions. In addition to the original attributes of stakeholder salience (Mitchell et al., 1997), our analysis supports "proximity" (Driscoll \& Starik, 2004) as an additional predictor of salience. Proximity was very relevant for explaining salience at the operational level; it involves physical as well as emotional proximity and empathy with the plight of informal miners. However, our findings do not support research that proposes an "organization," defined as efforts to find a collective voice, as a predictor of salience (Ali, 2017). Informal miners acted without apparent coordination nor a collective voice in groups defined by relations of kinship and transactions. They did not have national leaders or formal alliances, which made them more difficult to deal with.

Finally, our study confirms that MNEs have an important role to play in the design of new solutions for the governance of natural resources, poverty alleviation, and sustainable development in host countries; they can legitimize fringe stakeholders and their claims through cooperation and engagement. Although cooperation with poor rivals seeking a livelihood is a form of co-management, we need to acknowledge that MNEs have more power in the relationship and thus, greater control of the solution's maintenance and outcomes. Cooperative strategies can become a stable response to conflict if they align with an appropriate stakeholder salience assessment and build mutual trust between stakeholders. Therefore, commitment of the MNEs to contribute to sustainable development in host nations is imperative for the successful delivery of cooperative strategies.

\subsection{Limitations and future research}


Our research uses a single case study design, applied to one country with a focus on gold mining as a sub-sector of the extractive industries. Future research may compare MNE relations with informal miners in other countries and explore empirical evidence for MNE collaborative arrangements in other resource rivalry situations. Future research on informal resource use can expand the scope of analysis to global value chains and include other global stakeholders in the analysis. Conceptually, corporate approaches to informal resource users in emerging markets can be further explored using institutional voids (Khanna \& Palepu, 2010), poverty alleviation, and ethical trading as part of CSR programs (Kolk, 2016), and bottom of the pyramid approaches (Prahalad, 2006).

The proposed SIAD analysis of stakeholder salience across governance levels can be combined with knowledge transfer and transaction-costs perspectives to analyze the scalability of solutions to sustainability challenges. Despite its implications for sustainable development and socially inclusive practices, there has been very little discussion on fringe stakeholders in international business literature (Hart \& Sharma, 2004). Future research could build on the SIAD framework to investigate solutions across governance levels for other types of rivalries and collaborative relationships between MNEs and fringe stakeholders.

\subsection{Managerial relevance}

Our research shows that seemingly fringe stakeholders can turn into rivals to be reckoned with by MNEs. We suggest that MNEs do not often engage with these stakeholders because their salience assessment has been misguided. The salience of informal rivals for resources has been negatively amplified by local governments. Misguided stakeholder assessments can lead to flaws in the design of corporate responses to business challenges and result in conflict, operational risks, and reputational damage. MNEs should build stakeholder 
assessments in close interaction with other legitimate stakeholders such as local communities. Concurring with the advice from international and industry organizations (ICMM, 2009; WB, 2009), we suggest that MNE cooperation with informal rivals coming from indigenous, poor communities in emerging markets can become a win-win solution contributing to the attainment of organizational goals of secure access to resources and improved societal legitimacy of MNEs in host countries (Gifford et al., 2010) and societal goals of sustainable development, environmental protection, and poverty alleviation in emerging markets.

For mining MNEs, supporting poverty-led ASM workers in sustaining their livelihoods is an imperative part of their CSR strategies. MNEs can take an active role in assisting ASM workers in social upgrading and up-skilling, providing technical expertise and improving ASM health and safety and environmental practices. Further initiatives can be explored in assisting informal miners to market their production. In the situation of interaction with informal rival actors whose legitimacy is contested on legal grounds but supported by informal and customary rules, companies need to rely on local stakeholder networks to assess the legitimacy of stakeholder claims. They also need to consider the overall stability of a governance solution for sustainable development.

\section{Conclusions}

Poverty and social inclusion are very relevant sustainable development issues to consider in the context of international business. Despite acknowledging the causal relation between informality, poverty, and social exclusion, the literature on CSR in developing countries has not investigated factors that drive cooperation between MNEs and informal rivals for natural resource use. We address this gap by introducing the SIAD framework, which proposes a dynamic salience assessment of informal rivals and a cooperative role for 
MNEs in governing natural resources. We contend that for ethical and instrumental reasons, it is important for mining MNEs to take a more active role in governing natural resources, assisting poor communities with historical and traditional links to resource use and contributing to legitimization of informal resource users through cooperation. Forced replacement of customary rules with formal rules imposed by the state and international organizations can struggle to deliver a stable governance of natural resources. In this context, MNEs adopting a political strategy to rely on state policies to deal with informal resource rivals will not only fail to secure tenure but can indirectly affect social and environmental sustainability in host countries.

The application of the SIAD framework allows MNEs to refine their strategies in a wider context of sustainable natural resource governance and its functional levels. We suggest that cooperation with unauthorized resource users offers an alternative third strategy to the exit or wait strategies (Khanna \& Palepu, 2010) when a political strategy fails to achieve organizational goals. This third way to secure tenure-through cooperation with informal resource users - can improve the security of the tenure and deliver sustainability benefits in terms of environmental protection, poverty alleviation, social inclusion, and employment support in local communities in emerging markets. Local environmental protection increases when MNEs coach artisanal miners on safe mining practices. MNEs play an important role in increasing the salience of fringe stakeholders within the businesscommunity-government nexus by "legitimization through engagement," and thus, improve the social inclusion of poor stakeholders. "Legitimization through engagement" enables social upgrading because it influences the attitudes of other stakeholders towards previously illegitimate social groups. This study demonstrates that stakeholder salience is a dynamic process of assessment across different governance levels, where stakeholders can gain salience bottom-up from operational to constitutional levels and can lose salience top-down. 
CSR and international business scholars can apply the SIAD framework to analyze competition between MNEs and informal rivals in other natural resource sectors such as forestry, fishing, or other extractive sectors. In addition, SIAD can be applicable to the analysis of other situations where MNEs compete with informal poor rivals, such as counterfeit goods producers and retailers, for access to markets. Wider application and expansion of the SIAD framework will result in better understanding of how MNEs can contribute to the fulfillment of SDGs, particularly to reduce poverty, inequality, and unsustainable use of natural resources.

\section{References}

Agle, B., Mitchell, R., \& Sonnenfeld, J. (1999). Who matters to CEOs? An investigation of stakeholder attributes and salience, corporate performance, and CEO values. Academy of Management Journal, 42(5): 507-525.

Ali, M. (2017). Stakeholder salience for stakeholder firms: An attempt to reframe an important heuristic device. Journal of Business Ethics, 144: 153-168.

Aubynn, A. (2009). Sustainable solution or a marriage of inconvenience? Coexistence of large-scale mining and artisanal and small-scale mining on Abosso Goldfields concession in Western Ghana. Resources Policy, 34: 64-70.

Batjargal, B., Hitt, M.A., Tsui, A.S., Arregle, J-L., Webb, J.W., \& Miller, T.L. (2013). Institutional polycentrism, entrepreneurs' social networks, and new venture growth. Academy of Management Journal, 56 (4): 1024-1049. 
Bebbington, A. (Ed.) (2012). Social conflict, economic development and extractive industry: Evidence from South America. London: Routledge.

Boddewyn, J.J. (2016). International business-government relations research 1945-2015: Concepts, typologies, theories and methodologies. Journal of World Business, 51: $10-22$.

Bundy, J., Shropshire, C., \& Buchholtz, A.K. (2013). Strategic cognition and issue salience: Toward an explanation of firm responsiveness to stakeholder concerns. Academy of Management Review, 38: 352-76.

Bush, R. (2009). Soon there will be no-one left to take the corpses to the morgue': Accumulation and abjection in Ghana's mining communities. Resources Policy, 34: $57-63$.

Campbell, J.T., Eden, L., \& Miller, S.R. (2012). Multinationals and corporate social responsibility in host countries: Does distance matter? Journal of International Business Studies, 43: 84-106.

Charmaz, K. (2006). Constructing grounded theory: A Practical guide through qualitative analysis. London: Sage Publications.

Clement, F. (2010). Analysing decentralised natural resource governance: proposition for "politicised" institutional analysis and development framework. Policy Science, 43: 129-156.

Crilly, D. (2011). Predicting stakeholder orientation in the multinational enterprise: A midrange theory. Journal of International Business Studies, 42(5): 694-717. 
Dahan, N.M., Doh, J.P., \& Raelin, J.D. (2015). Pivoting the Role of Government in Business and Society Interface: A Stakeholder Perspective. Journal of Business Ethics, 131: $665-680$.

Demuijnck, G., \& Ngnodjom, H. (2013). Responsibility and informal CSR in formal Cameroonian SMEs. Journal of Business Ethics, 112 (4): 653-665.

Den Hond, F. \& De Bakker, F.G.A. (2007). Ideologically motivated activism: How activist groups influence corporate social change activities. Academy of Management Review, 32 (3): 901-924.

Dietz, T., Ostrom, E., \& Stern, P.C. (2003). The struggle to govern the commons. Science, 302: 1907-1912.

Doh, J.P. \& Teegen, H. (2002). Nongovernmental organizations as institutional actors in international business: Theory and implications. International Business Review, 11: $665-684$.

Donaldson, T., \& Preston, L.E. (1995). The stakeholder theory of the corporation: Concepts, evidence, and implications. Academy of Management Review, 20 (1): 65-91.

Driscoll, C., \& Starik, M. (2004). The primordial stakeholder: Advancing the conceptual consideration of stakeholder status for the natural environment. Journal of Business Ethics, 49: 55-73.

Dunning, J.H. (1988). The eclectic paradigm of international production: A restatement and some possible extensions. Journal of International Business Studies, 19(1): 1-31.

Dunning, J.H. (1998). Location and the multinational enterprise: A neglected factor? Journal of International Business Studies, 29(1): 45-66. 
Erdiaw-Kwasie, M.O., Alam, K., \& Shahiduzzaman, M. (2017). Towards understanding stakeholder salience transition and relational approach to 'better' corporate social responsibility. Journal of Business Ethics, 144, 85-101.

Fassin, Y. (2010). A dynamic perspective in Freeman's stakeholder model. Journal of Business Ethics, 96: 9-49.

Freeman, R.E. (1984). Strategic management: A stakeholder approach. Boston: Pitman Publishing Inc.

Friedman, A.L., \& Miles, S. (2002). Developing stakeholder theory. Journal of Management Studies, 39: 1-21.

Frynas, J.G. (2010). Corporate social responsibility and societal governance: lessons from transparency in the oil and gas sector. Journal of Business Ethics, 93(2): 163-179.

Gifford, B., Kestler, A., \& Anand, S. (2010). Building local legitimacy into corporate social responsibility: Gold mining firms in developing nations. Journal of World Business, 45 (3): 304-311.

Hart, S.L., \& Sharma, S. (2004). Engaging fringe stakeholders for competitive imagination. Academy of Management Executive, 18(1): 7-18.

Hillman, A.J., \& Hitt, M.A. (1999). Corporate political strategy formulation: A model of approach, participation, and strategy decisions. Academy of Management Review, 24(4): 825-842.

Hilson, G., Yakovleva, N., \& Banchirigah, S.M. (2007). 'To move or not to move': Reflections on resettlements of artisanal miners in the Western Region of Ghana. African Affairs, 106: 413-436. 
Hirons, M. (2014). Decentralising natural resource governance in Ghana: Critical reflections on the artisanal and small-scale mining sector. Futures, 62: 21-31.

Holmes, R.M., Miller, T.L., Hitt, M.A., \& Salmador, M.P. (2013). The interrelationships among informal institutions, formal institutions, and inward Foreign Direct Investment. Journal of Management, 39(2): 531-566.

International Council for Mining and Metals (ICMM) (2009). Working together - How largescale miners can engage with artisanal and small-scale miners. ICMM: London. Available from: http://www.icmm.com/document/789 (accessed 17 May 2016).

International Labour Organization (ILO) (2017). Formalization and the UN SDGs, ILO GB.329/POL/2. Geneva: ILO.

Kapelus, P. (2002). Mining, corporate social responsibility and the "community": The case of Rio Tinto, Richards Bay Minerals and Mbonambi. Journal of Business Ethics, 39: 275-296.

Keenan, J.C., Kemp, D., \& Ramsay, R.B. (2016). Company-community agreements, gender and development. Journal of Business Ethics, 135: 607-615.

Khanna, T., \& Palepu, K. (2010). Winning in emerging markets: A road map for strategy and execution. Boston: Harvard Business School Press.

Khurram, S., \& Charreire Petit, S. (2017). Investigating the dynamics of stakeholder salience: What happens when the institutional change process unfolds? Journal of Business Ethics, 143: 485-515.

Kolk, A. (2016). The social responsibility of international business: From ethics and the environment to CSR and sustainable development. Journal of World Business, 51: 23-34. 
Kolk, A., Kourula, A. \& Pisani, N. (2017) Multinational enterprises and the Sustainable Development Goals: What do we know and how to proceed? Transnational Corporation, Published online 20 June 2017.

Koontz, T.M. (2006). Collaboration for sustainability? A framework for analyzing government impacts in collaborative-environmental management. Sustainability: Science, Practice, \& Policy, 2(1): 15-24.

Kostova, T., \& Zaheer, S. (1999). Organizational legitimacy under conditions of complexity: The case of the multinational enterprise. Academy of Management Review, 24(1): 64-81.

Kraemer, R., Whiteman, G., \& Banerjee, B. (2013). Conflict and astroturfing in Niyamgiri: The importance of national advocacy networks in anti-corporate social movement. Organization Studies, 34: 823-852.

Lincoln, Y.S., \& Guba, E.G. (1985). Naturalistic inquiry. Beverly Hills, California: Sage Publications.

Lund-Thomsen, P., Lindgreen, A., \& Vanhamme, J. (2016). Industrial clusters and corporate social responsibility in developing countries: what we know, what we do not know, and what we need to know. Journal of Business Ethics, 133(1): 9-24.

Luo, Y., \& Zhao, H. (2013). Doing business in a transitional society: Economic environment and relational political strategy for multinationals. Business \& Society, 52(3): 515549.

Mitchell, R.K., Agle, B.R., \& Wood, D.J. (1997). Toward a theory of stakeholder identification and salience: Defining the principle of who and what really counts. Academy of Management Review, 22(4): 853-886. 
Organization for Economic Cooperation and Development (OECD) (2015). Responsible supply chains in artisanal and small-scale gold mining. Available from: http://www.oecd.org/daf/inv/investment-policy/FAQ_Sourcing-Gold-from-ASMMiners.pdf (accessed on 20/06/2017).

Ostrom, E. (1990). Governing the commons: The evolution of institutions for collective action. Cambridge, UK: Cambridge University Press.

Ostrom, E. (2007). A diagnostic approach for going beyond panaceas. Proceedings of the National Academy of Sciences of the Unites States of America, 104(39): 1518115187

Ostrom, E. (2010). Beyond markets and states: Polycentric governance of complex economic systems. American Economic Review, 100: 641-672.

Ostrom, E., \& Gardner, R. (1993). Coping with asymmetries in the commons: self-governing irrigation systems can work. Journal of Economic Perspectives, 7(4): 93-112.

Ostrom, E., Gardner, R., \& Walker, J. (1994). Rules, games and common-pool resources. Ann Arbor: The University of Michigan Press.

Paavola, J. (2007). Institutions and environmental governance: A reconceptualization. Ecological Economics, 63: 93-102.

Paavola, J. (2008). Governing atmospheric sinks: the architecture of entitlements in the global commons. International Journal of the Commons, 2(2): 313-336.

Paavola, J. (2016). Multi-level environmental governance: Exploring the economic explanations. Environmental Policy and Governance, 26: 143-154. 
Peng, M.W., Wang, D.Y.L., \& Jiang, Y. (2008). An institution-based view of international business strategy: A focus on emerging economies. Journal of International Business Studies, 39(5): 920-936.

Phillips, R., Freeman, R.E., \& Wicks, A.C. (2003). What stakeholder theory is not? Business Ethics Quarterly, 13(4): 479-50.

Prahalad, C.K. (2006). The fortune at the Bottom of the Pyramid. Upper Saddle River, NJ: Prentice Hall.

Ramamurti, R. (2004). Countries and MNEs: Extending and enriching the research agenda. Journal of International Business Studies, 35(4): 277-283.

Rivera-Santos, M., Holt, D., Littlewood, D., \& Kolk, A. (2015). Social entrepreneurship in sub-Saharan Africa. The Academy of Management Perspectives, 29(1): 72-91.

Saldarriaga-Isaza, A., Villegas-Palacio, C., \& Arango, S. (2013). The public good dilemma of a non-renewable common resource: The facts of artisanal gold mining. Resources Policy, 38: 224-232.

Shivarajan, S., DuBois, T., \& Srinivasan, A. (2015). Examining how marginalized stakeholders successfully redress their issues: A social networks approach. Annals in Social Responsibility, 1(1): 108-130.

Stevens, C.E., Xie, E., \& Peng, M.W. (2016). Toward a legitimacy-based view of political risk: the case of Google and Yahoo in China. Strategic Management Journal, 37: 945-963.

Suchman, M. C. (1995). Managing legitimacy: Strategic and institutional approaches. Academy of Management Review, 20(3): 571-610. 
Svensson, G., Wood, G., \& Callaghan, M. (2010). A corporate model of sustainable business practices: An ethical perspective. Journal of World Business, 45(4): 336-345.

Tashman, P., \& Raelin, J. (2013). Who and what really matters to the firm: Moving stakeholder salience beyond managerial perceptions. Business Ethics Quarterly, 23(14): 591-616.

Tschakert, P., \& Singha, K. (2007). Contaminated identities: Mercury and marginalization in Ghana's artisanal mining sector. Geoforum, 38: 1304-1321.

Veiga, M.M., Angeloci-Santos, G., \& Meech, J.A. (2014). Review of barriers to reduce mercury use in artisanal gold mining, The Extractive Industries and Society, 1: 351361.

Verbrugge, B., \& Besmanos, B. (2016). Formalizing artisanal and small-scale mining: Whither the workforce? Resources Policy, 47: 134-141.

World Bank (WB) (2009). Mining together: Large-scale mining meets artisanal mining - A guide for action. Washington, DC: World Bank.

Yakovleva N., \& Vazquez-Brust, D.A. (2014). Multi-stakeholder international governance initiatives: Addressing challenges of ASM in Ghana. In: Vazquez-Brust, Sarkis and Cordeiro (Eds). Collaboration for Sustainability and Innovation: A Role of Sustainability Driven by the Global South? (pp. 127-148) Dordrecht, Netherlands: Springer.

Yin, R. K. (2003). Case Study Research: Design and Methods. Thousand Oaks, CA: Sage Publications. 
Zheng, Q., Luo, Y., \& Maksimov, V. (2015). Achieving legitimacy through corporate social responsibility: The case of emerging economy firms. Journal of World Business, 50(3): 389-403.

Zheng, Y., Zhao, W. \& Ge, J. (2016). Institutional duality and political strategies of foreigninvested firms in an emerging economy. Journal of World Business, 51: 451-462. 
Table 1. Interviews with the range of actors in the ASM sector in Ghana, 2005-2008

\begin{tabular}{lll}
\hline Range of actors & $\mathbf{2 0 0 5}$ & $\mathbf{2 0 0 8}$ \\
\hline Government departments & 5 & 6 \\
$-\quad$ Senior and middle tier officials at the national level & 4 & 6 \\
$-\quad$ Official at the local level & 1 & 0 \\
Small-scale miners and buyers & 4 & 0 \\
- Registered small-scale miner & 2 & 0 \\
- Gold buyers & 1 & 1 \\
- Unregistered small-scale miner & 1 & 0 \\
Non-governmental organizations (NGO)/academia & & 2 \\
$-\quad$ University & 3 & 1 \\
$-\quad$ National NGO & 0 & 1 \\
- Local NGO & 1 & 0 \\
Large-scale MNEs and industry associations & 2 & 2 \\
- Large-scale MNEs & & 2 \\
$-\quad$ National mining association & 4 & 0 \\
Total & 3 & 10 \\
\hline
\end{tabular}


Table 2. Political strategy vs. cooperative strategy to manage mineral resource conflict

\begin{tabular}{|c|c|c|}
\hline Functions of resource use solutions (Paavola, 2016) & $\begin{array}{c}\text { Political strategy } \\
\text { (state-based solution) }\end{array}$ & $\begin{array}{c}\text { Cooperative strategy } \\
\text { (stakeholder management solution) }\end{array}$ \\
\hline Exclusion of unauthorized users & $\begin{array}{l}\text { Government excludes un-registered, informal resource } \\
\text { users from accessing the resource. }\end{array}$ & $\begin{array}{l}\text { MNEs collaborate with informal resource users in the } \\
\text { concession to share access to resources and exclude } \\
\text { new entrants. }\end{array}$ \\
\hline $\begin{array}{l}\text { Regulation of authorized use and distribution of } \\
\text { benefits }\end{array}$ & $\begin{array}{l}\text { Government regulates authorized users only and the } \\
\text { benefits are distributed between the state and the } \\
\text { authorized users. }\end{array}$ & $\begin{array}{l}\text { MNEs negotiate regulation directly with informal } \\
\text { resource users in the concession and decide how to } \\
\text { share the benefits of accessing the resources with } \\
\text { them. }\end{array}$ \\
\hline $\begin{array}{l}\text { Provisioning of rival and non-rival goods and recovery } \\
\text { of costs }\end{array}$ & $\begin{array}{l}\text { Government provides technical assistance to registered } \\
\text { resource users only. Both registered and unregistered } \\
\text { resource users can sell the resource through state-run } \\
\text { network of agents. }\end{array}$ & $\begin{array}{l}\text { MNEs can provide technical assistance to informal } \\
\text { resource users. Both registered and unregistered } \\
\text { resource users can sell the resource through a state-run } \\
\text { network of agents. }\end{array}$ \\
\hline $\begin{array}{l}\text { Monitoring of resource users and their compliance } \\
\text { with rules }\end{array}$ & Government monitors authorized users. & $\begin{array}{l}\text { MNEs monitor informal resource users in their area of } \\
\text { operations. }\end{array}$ \\
\hline Enforcement of rules of resource use & $\begin{array}{l}\text { Government removes unauthorized users by force and } \\
\text { dialogue. }\end{array}$ & $\begin{array}{l}\text { Informal resource users collaborating with MNEs } \\
\text { prevent other unauthorized users from accessing the } \\
\text { resource. }\end{array}$ \\
\hline Resolution of conflicts over resource use & $\begin{array}{l}\text { Government resolves the conflict with force and } \\
\text { dialogue. }\end{array}$ & $\begin{array}{l}\text { MNEs resolve conflict with informal resource users } \\
\text { through direct negotiation and involvement of } \\
\text { customary authorities. }\end{array}$ \\
\hline $\begin{array}{l}\text { Decision-making and collective-choice for } \\
\text { modification of governance solutions }\end{array}$ & $\begin{array}{l}\text { Government allows only authorized resource users to } \\
\text { participate in design of solutions. }\end{array}$ & $\begin{array}{l}\text { MNEs allow selected informal resource users and } \\
\text { customary authorities to participate in negotiations on } \\
\text { resource use solutions. }\end{array}$ \\
\hline
\end{tabular}


Table 3. Government attitudes towards small-scale miners in Ghana, 2005-2008

\section{Illegal miners}

"Galamsey in this country, means people who are actually working on small-scale mining basis illegally. You can look at him as an armed robber." (Government Official 1).

Illegal

"Galamsey activities are illegal. It's like saying; do you recognize an armed robber? Yes, I don't think we should condone illegality" (Government Official 2).

\section{Unregistered miners}

"For me I think that's not really illegal [...] I see them as unregistered small-scale miners and I said by virtue of the fact that everybody is competing for that piece of land and you (MNEs) have been given the handshake first that does not mean that they were a criminal (Government Official 1).

\section{Informal}

"Galamsey are informal miners because they are contributing to the informal economy, they buy food and equipment from local communities. You need to understand in their culture, the land belongs to the community, even the chiefs do not own land" (Government Official 2). 
Figure 1. Stakeholder salience and governance levels

Constitutional level
A level where higher order rules are designed that affect both collective-choice and operational levels

\begin{tabular}{|c|c|}
$\begin{array}{c}\text { Fringe } \\
\text { stakeholder }\end{array}$ & Salience \\
stakeholder
\end{tabular}

Collective-choice level

A level where rules are designed and applied

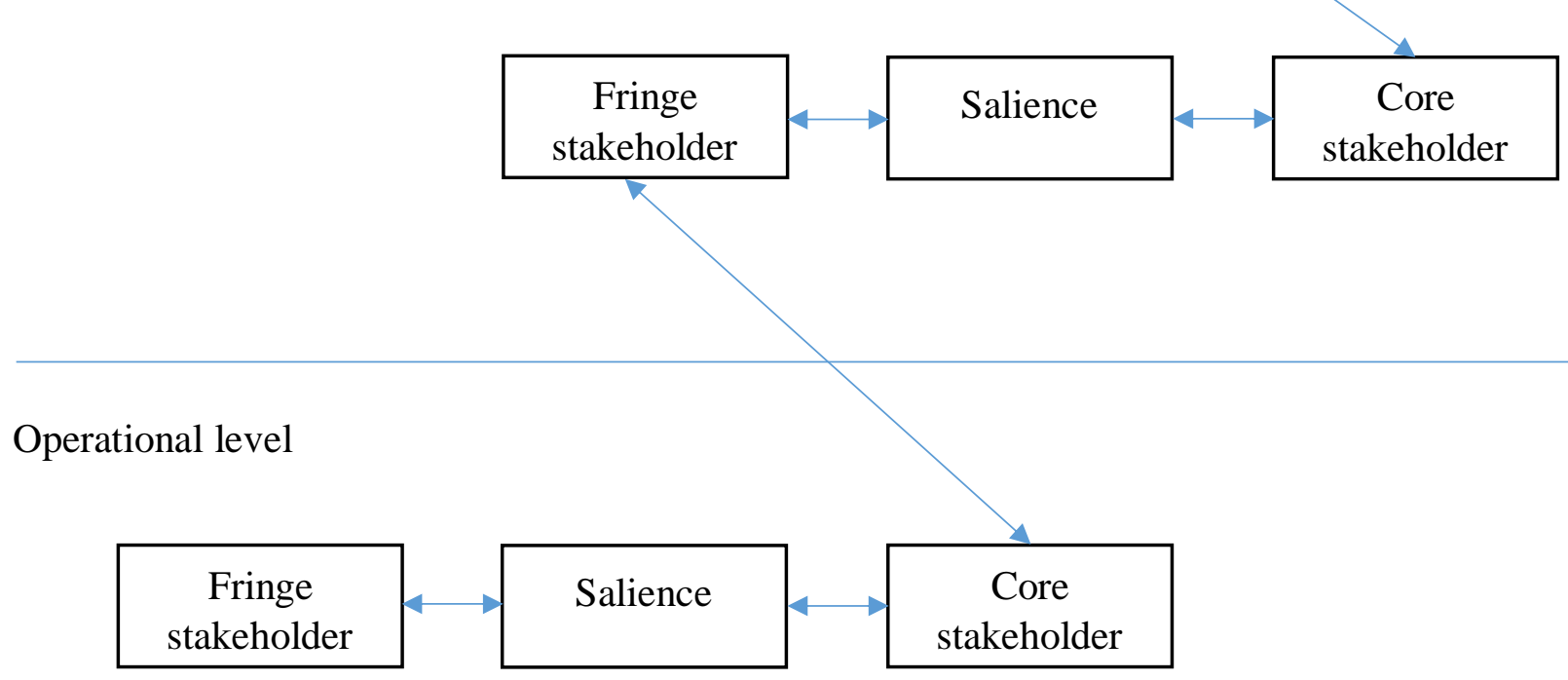

A level where decisions directly affect the physical world. 